Article

KHAN, M.J. ${ }^{1 *}$

AHMED, N. ${ }^{2}$

HASSAN, W. ${ }^{3}$

SABA, T. ${ }^{4}$ (D)

KHAN, S. ${ }^{5}$

KHAN, Q. ${ }^{1}$

\section{Evaluation of Phytoremediation Potential of Castor Cultivars fOR Heavy Metals From SoIl}

\author{
Avaliação do Potencial de Cultivares de Mamona na Fitorremediação de Solo \\ Contaminado por Metais Pesados
}

\begin{abstract}
Phytoremediation is a useful tool to restore heavy metals contaminated soils. This study was carried out to test two castor (Ricinus communis) cultivars [Local and DS-30] for phytoextraction of heavy metals from the soil spiked by known concentrations of seven metals $(\mathrm{Cu}, \mathrm{Cr}, \mathrm{Fe}, \mathrm{Mn}, \mathrm{Ni}, \mathrm{Pb}$ and $\mathrm{Zn})$. A pot experiment was laid out by using a completely randomized design. Soil and plant samples were analyzed at 100 days after planting. The data on heavy metal uptake by plant tissues (roots, leaves and shoots) of the two castor cultivars suggested that a considerable amount of metals $\left(\mathrm{Fe}=27.18 \mathrm{mg} \mathrm{L}^{-1} ; \mathrm{Cu}=5.06 \mathrm{mg} \mathrm{L}^{-1} ; \mathrm{Cr}=2.95 \mathrm{mg} \mathrm{L}^{-1}\right.$; $\mathrm{Mn}=0.22 \mathrm{mg} \mathrm{L}^{-1} ; \mathrm{Ni}=4.66 \mathrm{mg} \mathrm{L}^{-1} ; \mathrm{Pb}=3.33 \mathrm{mg} \mathrm{L}^{-1} ; \mathrm{Zn}=15.04 \mathrm{mg} \mathrm{L}^{-1}$ ) was accumulated in the plant biomass. The soil heavy metal content at the end of experiment significantly decreased with both cultivars, resulting in improved soil quality. Therefore, it is concluded that both castor cultivars, Local and DS-30, can be used for phytoremediation of heavy metal-contaminated sites.
\end{abstract}

Keywords: phytotoxins, soil contaminants, phytoextraction.

RESUMO - A fitorremediação é uma ferramenta útil para recuperar solos contaminados com metais pesados. Este estudo foi realizado para testar dois cultivares de mamona (Ricinus communis) [Local e DS-30] quanto à fitoextração de metais pesados de solo contaminado por concentrações conhecidas de sete metais ( $\mathrm{Cu}, \mathrm{Cr}, \mathrm{Fe}, \mathrm{Mn}, \mathrm{Ni}, \mathrm{Pb}$ e $\mathrm{Zn}$ ). Um ensaio em vasos foi instalado com um delineamento completamente casualizado. Cem dias após o plantio, foram analisadas amostras do solo e das plantas. Os dados referentes à absorção de metais pesados pelos tecidos vegetais (raízes, folhas e parte aérea) dos dois cultivares de mamona sugerem que quantidades consideráveis de metais (Fe = 27,18 $\mathrm{mg} \mathrm{L}^{-1} ; \mathrm{Cu}=5,06 \mathrm{mg} \mathrm{L}^{-1} ; \mathrm{Cr}=2,95 \mathrm{mg} \mathrm{L}^{-1} ; \mathrm{Mn}=0,22 \mathrm{mg} \mathrm{L}^{-1} ; \mathrm{Ni}=$ 4,66 $\mathrm{mg} \mathrm{L}^{-1} ; \mathrm{Pb}=3,33 \mathrm{mg} \mathrm{L}^{-1} ; \mathrm{Zn}=15,04 \mathrm{mg} \mathrm{L}^{-1}$ ) foram acumuladas na biomassa da planta. Foi observada redução significativa do teor de metais pesados no solo ao final do experimento com os dois cultivares, resultando em melhor qualidade do solo. Portanto, conclui-se que ambos os cultivares de mamona, Local e DS-30, podem ser utilizados para a fitorremediação de locais contaminados com metais pesados.

Palavras-chave: fitotoxinas, contaminantes do solo, fitoextração.

Received: June 6, 2017

Approved: January 22, 2018

\section{Copyright: This is an open-access article distributed under the terms of the Creative Commons Attribution License, which permits unrestricted use, distribution, and reproduction in any medium, provided that the original author and source are credited. \\ Planta Daninha 2019; v37:e019180998}

${ }^{1}$ Department of Soil \& Environmental Sciences, Faculty of Agriculture, Gomal University, Dera Ismail Khan, 29050, KPK, Pakistan; ${ }^{2}$ Department of Soil Science, Faculty of Agricultural Sciences \& Technology, Bahauddin Zakariya University, Multan 60800, Pakistan; ${ }^{3}$ Muhammad Nawaz Shareef University of Agriculture, Multan, Pakistan; ${ }^{4}$ Department of Botany, University of the Punjab, Lahore, Pakistan; ${ }^{5}$ University WENSAM College, Gomal University, Dera Ismail Khan, 29050, KPK, Pakistan. 


\section{INTRODUCTION}

Heavy metal (HM) contamination of terrestrial ecosystems has been accelerated in the past few decades (Atibu et al., 2013). HMs such as $\mathrm{Cu}, \mathrm{Fe}, \mathrm{Se}, \mathrm{Ni}, \mathrm{Pb}$ etc. are of great concern because these are very persistent, stable and bio-accumulative (Al-Wabel, 2007). Unlike organic pollutants, HMs are non-biodegradable, hence they pose serious public health risks through food chain and loss of biodiversity (Peng et al., 2008). Certain HMs are toxic even at low concentrations and can affect crop production (Yi et al., 2011). Heavy metals are naturally found in soils, and plants use their minute amounts as essential metabolites. In recent years, anthropogenic activities have resulted in enormous increase in both type and concentration of heavy metals in the soil (Mahmood and Malik, 2014). Discharge of contaminated industrial effluents, and atmospheric deposition have been posing a greater threat to ecological integrity of developing countries, e.g., Pakistan. In agricultural soils of Pakistan, presence of HMs has been reported by many workers, and a few sites even show higher HM concentrations than the limits set by the World Health Organization. For instance, Khan et al. (2013) reported that Cd concentration was found to be higher than the limit $\left(0.05 \mathrm{mg} \mathrm{kg}^{-1}\right)$ set by the World Health Organization in agricultural soils of Swat District, northern Pakistan (Khan et al., 2013).

Restoration of our ecosystems from the adverse effects of contaminants is very expensive for the functionality of living systems (Wiszniewska et al., 2016). For example, remediation of contaminated sites in the European Union would cost an estimated amount of $€ 17.3$ billion/ annum (Bauddh and Singh, 2012). In developing countries such as Pakistan, where population densities are enormous and available resources are limited, a low-cost and ecologically sustainable technology is required to remediate contaminated soil as well as to minimize the associated environmental risks. This in turn also increases the available land resources for agricultural production thus also enhances food security (Back and Rosén, 2006).

Amongst the strategies for reclamation of HM polluted systems, phytoremediation has emerged as one of the least expensive and most reliable technologies in recent years (Cundy et al., 2013). Phytoremediation is a green solution to HM contamination which uses hyperaccumulating green plants to remove, destroy or sequester hazardous substances from the environment (Tangahu et al., 2011). Another important part of phytoremediation is identification and characterization of HM accumulators from natural flora. It is also established that some plant species are endemic to metal contaminated soils and can tolerate greater than usual amounts of heavy metals or other toxic compounds (Schat et al., 2000). Castor bean, a highly adaptive plant, has been identified as a metal tolerant plant under a variety of climatic conditions (Olivares et al., 2013). Moreover, the castor bean plant has received more attention because of its high seed oil yields for synthesis of biofuel in recent years (Berman et al., 2011). For this reason, castor was selected as plant of choice.

The objective of this experiment was to explore the phytoremediation potential of castor bean when grown in soil contaminated with different metals and compare the HM uptake abilities of the selected castor bean cultivars.

\section{MATERIALS AND METHODS}

Considering the importance of $R$. communis, the phytoextraction potentials of two cultivars of $R$. communis (Local and DS-30) were tested against these heavy metals. For this purpose, the surface soil $(20 \mathrm{~cm})$ from the field currently under wheat-rice cultivation was collected and processed for presence of any roots and debris. Clayey pots of $10 \mathrm{~kg}$ soil capacity were filled with soil, and healthy castor seeds were selected based on their appearance from both varieties. Suggested solutions with varying heavy metal concentrations (Table 1) were prepared, labeled and stored for further use in preparation of various the treatments. The control set of pots was filled with normal garden soil while the experimental set of pots was provided with solutions containing seven different $\mathrm{HMs}(\mathrm{Cu}, \mathrm{Cr}, \mathrm{Fe}, \mathrm{Mn}, \mathrm{Ni}, \mathrm{Pb}$ and $\mathrm{Zn})$ added to soil, and then each pot was labeled accordingly. Initially, five seeds per pot were sown and once germination was achieved and plantlets were established they were reduced to only one seedling per pot. Each treatment had three replicates along with the control set of pots while a completely random experimental setup was followed. The experiment was carried out at the Department of Soil and Environmental 
Table 1 - Concentration of heavy metals applied in the experiment

\begin{tabular}{|c|l|l|}
\hline S. No. & \multicolumn{1}{|c|}{ Heavy metal } & \multicolumn{1}{c|}{ Concentration $\left(\mathrm{mg} \mathrm{kg}^{-1}\right)$} \\
\hline 1 & Copper $(\mathrm{Cu})$ & $5,10,20$ and 40 \\
\hline 2 & Chromium $(\mathrm{Cr})$ & $1,2,4$ and 8 \\
\hline 3 & Iron $(\mathrm{Fe})$ & $10,20,40$ and 80 \\
\hline 4 & Manganese $(\mathrm{Mn})$ & $10,20,40$ and 80 \\
\hline 5 & Nickel $(\mathrm{Ni})$ & $5,10,20$ and 40 \\
\hline 6 & Lead $(\mathrm{Pb})$ & $2,4,8$ and 16 \\
\hline 7 & Zinc $(\mathrm{Zn})$ & $10,20,40$ and 80 \\
\hline
\end{tabular}

\section{Collection and analysis of soil and plant samples for heavy metals}

Spiked soil in all pots was analyzed at 100 days (after passing through several wetting and drying stages) after planting castor beans. The samples were placed in plastic bags, air dried, ground with wooden mortar and pestle and then sieved through a $2 \mathrm{~mm}$ sieve. The soil samples underwent microwave-assisted aqua regia digestion $\left(8 \mathrm{~mL}\left(\mathrm{HCL} / \mathrm{HNO}_{3} 3: 1\right)\right.$ for determination of total heavy metal content. Deionized water was used in the extraction procedure, based on the German Standard Method DIN 38414-S4. The available heavy metal content in soil samples was determined by 0.005 M DTPA extraction (Lindsay and Norvell, 1978). For this purpose, $10 \mathrm{~g}$ of soil sample was shaken with $20 \mathrm{~mL}$ of the extractant $\left(0.005 \mathrm{~mol} \mathrm{~L}^{-1}\right.$ diethylenetriaminepentaacetic acid $+0.1 \mathrm{~mol} \mathrm{~L}^{-1}$ triethanolamine + $0.01 \mathrm{~mol} \mathrm{~L}^{-1} \mathrm{CaCl}_{2}$, solution at $\mathrm{pH}$ 7.3) for two hours, centrifuged and then filtered. Metal contents in the samples were determined by an atomic absorption spectrophotometer (AAS Model GBC SAVANTAA, Australia). HM content was calculated by using the following formula:

$\mathrm{HM}$ content $\mathrm{mg} \mathrm{kg}^{-1}=$ Atm. abs $\times$ d. $\mathrm{f} \times 1000 /$ Vol. of sample in use $(\mathrm{g})$

Plant leaves, stems, branches and roots were collected at 100 days after sowing, washed with deionized water, oven-dried $\left(70^{\circ} \mathrm{C}\right)$, weighed and ground prior to analysis. All samples were digested in concentrated $\mathrm{HNO}_{3}$ in the laboratory using a microwave system and left overnight. Oven dried samples were ground and further extracted via wet digestion. After extraction, perchloric acid and $\mathrm{H}_{2} \mathrm{SO}_{4}$ were added to the samples, which were then digested on a hot plate $\left(120-140^{\circ} \mathrm{C}\right)$ inside the fume hood. The samples were placed in an ice bath, $25 \mathrm{~mL}$ distilled water was added, and then the samples were again heated to boil.Final volume of the extract was raised up to $100 \mathrm{~mL}$ prior to filtering. Metal contents in the diluted samples were determined by following the methods of Allen et al. (1986).

\section{Statistical Analysis}

All measurements were repeated three times, and the data were organized by using Microsoft Excel 2007 and presented as mean standard errors (SEs). Regression analysis for the results of each heavy metal was performed separately as described by Steel and Torrie (1984). The data were analyzed with PROC MIXED and PROC GLM commands for both variety and treatment to test the significant differences $(\mathrm{p}<0.05)$. The treatments were ranked with Duncan's Multiple Range test. Prior to analysis, data were checked for normality and homogeneity of variances.

Science, Gomal University, Dera Ismail Khan under the pot culture in the $\left(31^{\circ} 43^{\prime} 03.12^{\prime \prime} \mathrm{N}\right.$ samples of the soil prior to the experiment were analyzed for physico-chemical characteristics pot was also collected and analyzed for HM content $\mathrm{n}$ soil.

Table 2 - Physico-chemical characteristics of the soil in use

\begin{tabular}{|l|c|}
\hline \multicolumn{1}{|c|}{ Propertie } & Value \\
\hline Texture & Loamy sand \\
\hline $\mathrm{pH}$ & 7.96 \\
\hline $\mathrm{EC}\left(\mu \mathrm{S} \mathrm{cm}^{-1}\right)$ & 643 \\
\hline Extractable P $\left(\mathrm{mg} \mathrm{kg}^{-1}\right)$ & 6.12 \\
\hline Lime $(\%)$ & 19.33 \\
\hline Organic matter $(\%)$ & 0.64 \\
\hline Extractable K $\left(\mathrm{mg} \mathrm{kg}^{-1}\right)$ & 129.5 \\
\hline Extractable Na & 92.9 \\
\hline $\mathrm{SAR}$ & 8.7 \\
\hline $\mathrm{Cu}\left(\mathrm{mg} \mathrm{kg}^{-1}\right)$ & 0.08 \\
\hline $\mathrm{Cr}\left(\mathrm{mg} \mathrm{kg}^{-1}\right)$ & 0.07 \\
\hline $\mathrm{Fe}\left(\mathrm{mg} \mathrm{kg}^{-1}\right)$ & 0.96 \\
\hline $\mathrm{Mn}\left(\mathrm{mg} \mathrm{kg}^{-1}\right)$ & 0.09 \\
\hline $\mathrm{Ni}\left(\mathrm{mg} \mathrm{kg}^{-1}\right)$ & 0.16 \\
\hline $\mathrm{Pb}\left(\mathrm{mg} \mathrm{kg}^{-1}\right)$ & 0.07 \\
\hline $\mathrm{Zn}\left(\mathrm{mg} \mathrm{kg}^{-1}\right)$ & 1.32 \\
\hline
\end{tabular}




\section{RESULTS AND DISCUSSION}

\section{Heavy metal concentration of the soil}

It was also found that the soil where the local cultivar was grown showed greater Mn content than DS-30. Concentration of $\mathrm{Ni}, \mathrm{Pb}$ and $\mathrm{Zn}$ showed a significant difference in comparison to the variable concentration of the heavy metals applied to the soil. Significant interaction was observed between soil HM content and castor cultivar (Table 3). It is further assumed that castor is a high biomass-producing plant with broad leaves; therefore, it might have accumulated the available heavy metals rapidly, hence a lesser amount was left in the soil.

Table 3 - Comparison of $\mathrm{Ni}, \mathrm{Pb}$ and $\mathrm{Zn}$ content $\left(\mathrm{mg} \mathrm{kg}^{-1}\right)$ left in the soil

\begin{tabular}{|c|c|c|c|c|c|c|c|c|c|c|c|c|c|c|c|}
\hline \multirow{2}{*}{ Cultivar } & \multicolumn{4}{|c|}{ Ni Content $\left(\mathrm{mg} \mathrm{L}^{-1}\right)$} & \multirow{2}{*}{ Mean } & \multicolumn{4}{|c|}{$\mathrm{Pb}$ Content $\left(\mathrm{mg} \mathrm{L}^{-1}\right)$} & \multirow{2}{*}{ Mean } & \multicolumn{4}{|c|}{$\mathrm{Zn}$ Content $\left(\mathrm{mg} \mathrm{kg}^{-1}\right)$} & \multirow{2}{*}{ Mean } \\
\hline & 5 & 10 & 20 & 40 & & 5 & 10 & 20 & 40 & & 5 & 10 & 20 & 40 & \\
\hline Local & $0.39 \mathrm{~b}$ & $0.86 \mathrm{~b}$ & $1.76 \mathrm{~b}$ & $4.11 \mathrm{a}$ & $1.78^{\mathrm{NS}}$ & $0.41 \mathrm{~b}$ & $0.89 \mathrm{~b}$ & $1.35 \mathrm{~b}$ & $3.46 \mathrm{a}$ & $1.52^{\mathrm{NS}}$ & $2.66 \mathrm{e}$ & $6.05 \mathrm{de}$ & $10.0 \mathrm{~b}$ & $13.91 \mathrm{a}$ & $8.15^{\mathrm{NS}}$ \\
\hline DS - 30 & $0.46 \mathrm{~b}$ & $0.75 \mathrm{~b}$ & $1.18 \mathrm{~b}$ & $5.21 \mathrm{a}$ & 1.90 & $0.40 \mathrm{~b}$ & $0.85 \mathrm{~b}$ & $1.21 \mathrm{~b}$ & $3.20 \mathrm{a}$ & $1.41^{\mathrm{NS}}$ & $3.11 \mathrm{de}$ & $6.48 \mathrm{~cd}$ & $9.90 \mathrm{bc}$ & $16.18 \mathrm{a}$ & $8.91^{\mathrm{NS}}$ \\
\hline Mean & $0.42 \mathrm{~b}$ & $0.80 \mathrm{~b}$ & $1.47 \mathrm{~b}$ & $4.66 \mathrm{a}$ & & $0.40 \mathrm{~b}$ & $0.87 \mathrm{~b}$ & $1.28 \mathrm{~b}$ & $3.33 \mathrm{a}$ & & $2.88 \mathrm{~d}$ & $6.26 \mathrm{c}$ & $9.95 \mathrm{~b}$ & $15.04 \mathrm{a}$ & \\
\hline \multicolumn{2}{|c|}{ LSD Conc. } & & 1.10 & & & & & 0.89 & & & & & 2.60 & & \\
\hline \multicolumn{2}{|c|}{ LSD Cult. } & & NS & & & & & NS & & & & & NS & & \\
\hline \multicolumn{2}{|c|}{ LSD Conc. $\times$ Cult. } & & 1.56 & & & & & 1.26 & & & & & 3.69 & & \\
\hline
\end{tabular}

Means with similar letters do not differ significantly at $\mathrm{p}<0.05$.

This decreasing trend was the same in soil samples collected from the pots of both cultivars (Tables 4 and 5). There was maximum decrease in the soil spiked with the highest concentration of metals; i.e., Cu $40 \mathrm{mg} \mathrm{kg}^{-1}$, Cr $8 \mathrm{mg} \mathrm{kg}$, Fe $80 \mathrm{mg} \mathrm{kg}{ }^{-1}$, Mn $80 \mathrm{mg} \mathrm{kg}{ }^{-1}$, Ni $40 \mathrm{mg} \mathrm{kg}^{-1}$, $\mathrm{Pb} 16 \mathrm{mg} \mathrm{kg}^{-1}$ and $\mathrm{Zn} 80 \mathrm{mg} \mathrm{kg}^{-1}$, which proved that the castor plants accumulated a greater amount of metals in their biomass where the metals were available in excess amount. This also establishes the suitability of the plant as an effective accumulator of HMs and therfor castor cultivars can be successfully used for restoration of the HM affected soils. Very slight and nonsignificant differences were found in the comparison of soil samples analyzed for both cultivars, which shows that phytoremediation ability mainly depends upon the biomass of the plant rather than genotype. Based on these instant findings, it can be concluded that castor cultivars have maximum heavy metal uptake potential and are potential phytoremediators. Scientists have recently found that Castor oil plants can be used as phytoremediators of the contaminated soils because they are highly tolerant to high concentrations of $\mathrm{HMs}$, e.g., $\mathrm{Cu}, \mathrm{Fe}, \mathrm{Mn}$ and $\mathrm{Zn}$ (Abreu et al., 2012). Previous studies have also shown a decrease in $\mathrm{Zn}$ and $\mathrm{Cd}$ concentrations in soil as a result of plants uptake with passing more number of days (Uena et al., 2004). Puschenreiter et al. (2003) also found similar results in their study on heavy metal-contaminated soils.

\section{Uptake and accumulation of heavy metals in roots}

Results are indicative of a linear relationship between dosage of $\mathrm{HM}$ and their subsequent uptake by the plant's roots. Thus, maximum heavy metals were accumulated in the pots with the highest metal concentrations. Both cultivars took up an equal amount of all these metals, and there were no significant differences in uptake by the two genotypes. These findings are in line with the previous findings of Kozanecka et al., (2002), who also found similar trends of HM uptake in different forest plant species of Cladonia clavatum (wolf's claw), Dryopteris filix-mas (shield fern), Convalaria maialis (convallaria), and Vaccinium myrtillus (bilberry) in Poland. The instant results are slightly different from the previous findings of Knezevic et al., (2009). in which the level of heavy metals (Pb, Ni, Fe, $\mathrm{Zn}$ and $\mathrm{Mn}$ ) was compared in two species of plants, $P$. fortune and $P$. elongate, and $P$. elongate proved to be a hyperaccumulator of $\mathrm{Fe}$ and $\mathrm{Ni}$ as compared to $P$. fortune. Zhi-Xin et al. (2007) also reported slightly different results from their experiments: sunflower, Ricinus, alfalfa and mustard were used to test the bioaccumulation of $\mathrm{Pb}$ and $\mathrm{Cd}$ in hydroponic cultures. These slight differences in metal accumulation might be attributed to the different experimental conditions. Researchers also found that because of the well-known 
Table 4 - Comparison of Fe and Mn content $\left(\mathrm{mg} \mathrm{kg}^{-1}\right)$ left in the soil

\begin{tabular}{|l|c|c|c|c|c|c|c|c|c|c|}
\hline \multirow{2}{*}{ Cultivar } & \multicolumn{4}{|c|}{ Fe Content $\left(\mathrm{mg} \mathrm{L}^{-1}\right)$} & \multirow{2}{*}{ Mean } & \multicolumn{4}{c|}{ Mn Content $\left(\mathrm{mg} \mathrm{L}^{-1}\right)$} & \multirow{2}{*}{ Mean } \\
\cline { 2 - 8 } & 10 & 20 & 40 & 80 & & 10 & 20 & 40 & 80 & \\
\hline Local & $3.45 \mathrm{~d}$ & $6.11 \mathrm{~cd}$ & $11.91 \mathrm{~b}$ & $26.21 \mathrm{a}$ & $11.92^{\mathrm{NS}}$ & $0.11 \mathrm{~b}$ & $0.14 \mathrm{~b}$ & $0.15 \mathrm{~b}$ & $0.16 \mathrm{a}$ & $0.14 \mathrm{~b}$ \\
\hline DS - 30 & $3.91 \mathrm{~d}$ & $7.05 \mathrm{~b}$ & $10.65 \mathrm{~b}$ & $28.16 \mathrm{~b}$ & 12.44 & $0.18 \mathrm{~b}$ & $0.22 \mathrm{ab}$ & $0.25 \mathrm{ab}$ & $0.28 \mathrm{a}$ & $0.23 \mathrm{a}$ \\
\hline Mean & $3.68 \mathrm{~d}$ & $6.58 \mathrm{c}$ & $11.28 \mathrm{~b}$ & $27.18 \mathrm{a}$ & & 0.14 & 0.18 & 0.20 & 0.22 & \\
\hline LSD Conc. & & 1.2577 & & & & & NS & & \\
\hline LSD Cult. & & $\mathrm{NS}$ & & & & & 0.0434 & & \\
\hline LSD Conc. $\times$ Cult & & 2.9491 & & & & & 0.1523 & & \\
\hline
\end{tabular}

Mean with similar letters do not differ significantly at $\mathrm{p}<0.05$.

Table 5 - Comparison of $\mathrm{Cu}$ and $\mathrm{Cr}$ content $\left(\mathrm{mg} \mathrm{kg}^{-1}\right)$ left in the soil

\begin{tabular}{|c|c|c|c|c|c|c|c|c|c|c|}
\hline \multirow{2}{*}{ Cultivar } & \multicolumn{4}{|c|}{$\mathrm{Cu}$ Content $\left(\mathrm{mg} \mathrm{L}^{-1}\right)$} & \multirow{2}{*}{ Mean } & \multicolumn{4}{|c|}{ Cr Content $\left(\mathrm{mg} \mathrm{L}^{-1}\right)$} & \multirow{2}{*}{ Mean } \\
\hline & 5 & 10 & 20 & 40 & & 5 & 10 & 20 & 40 & \\
\hline Local & $0.600 \mathrm{~b}$ & $1.160 \mathrm{~b}$ & $2.060 \mathrm{c}$ & $4.980 \mathrm{a}$ & $2.20^{\mathrm{NS}}$ & $0.240 \mathrm{c}$ & $0.470 \mathrm{c}$ & $0.860 \mathrm{c}$ & $2.370 \mathrm{a}$ & $0.985^{\mathrm{NS}}$ \\
\hline DS - 30 & $0.660 \mathrm{~b}$ & $1.010 \mathrm{~b}$ & $2.060 \mathrm{~b}$ & $5.150 \mathrm{a}$ & 2.22 & $0.510 \mathrm{c}$ & $1.027 \mathrm{bc}$ & $1.043 \mathrm{bc}$ & $2.220 \mathrm{ab}$ & 1.200 \\
\hline Mean & $0.630 \mathrm{c}$ & $1.085 \mathrm{bc}$ & $2.060 \mathrm{~b}$ & $5.065 \mathrm{a}$ & & $0.375 \mathrm{c}$ & $0.748 \mathrm{bc}$ & $0.952 \mathrm{~b}$ & $2.295 \mathrm{a}$ & \\
\hline \multicolumn{2}{|c|}{ LSD Conc. } & & 1.2438 & & & & & 0.4944 & & \\
\hline \multicolumn{2}{|c|}{ LSD Cult. } & & NS & & & & & NS & & \\
\hline \multicolumn{2}{|c|}{ LSD Conc $\times$ Cult } & & 2.2842 & & & & & 1.2239 & & \\
\hline
\end{tabular}

Means with similar letters do not differ significantly at $\mathrm{p}<0.05$.

agronomic characteristics of cultivation and the high biomass production of switch grass, it is practicable to use switch grass for in situ phytoextraction of heavy metals (Chen et al, 2012). Other researchers also reported increased uptake of heavy metals by roots and leaves of vegetables during their experiments (Perveen, et al., 2011).

\section{Uptake of heavy metals by plant parts}

Plant biomass analysis of heavy metal uptake from the spiked soil by two castor cultivars (Local and DS-30). Heavy metal uptake by both cultivars sgowed a significant linear increase with increasing concentrations of heavy metals. Maximum uptake of HMs occurred in those plants which were treated with higher concentrations compared to the pots with lower heavy metal concentrations. Similarly, maximum linear increase of the study heavy metals was found in the plant samples collected after an interval of 100 days. Uptake performance of both Castor cultivars (Local and DS-30) was statistically at par with each other at each comparative concentration, which shows that the uptake ability of castor is not dependent upon genotype.

Based on these findings, it can be safely estimated that castor plants have accumulated a substantial amount of heavy metals in their biomass and can remediate heavy metalcontaminated soils. The instant findings are supported by the results of Kozanecka et al., (2002), who reported that heavy metal accumulation increased in plants with increasing intervals. Gregory and Crowder (1983) also found increased accumulation of metals (Cu, Ni, Zn, Fe, Mn and $\mathrm{Mg}$ ) in tissues of Typha latifolia collected from the contaminated soils. Zeittouni et al., (2007) also studied Castor as phytoremediator and found similar findings for $\mathrm{Zn}$ uptake. Homer et al. (1991) and Niu et al. (2007) also found similar results for accumulation of $\mathrm{HM} \mathrm{(Fe,} \mathrm{Ni}, \mathrm{Cr}, \mathrm{Cu}, \mathrm{Pb}$ and $\mathrm{Cd}$ ) in different plant species. Various other studies also revealed that metals are accumulated in plant parts during their growth on contaminated soils (Kumar et al., 1985; Zacchini et al., 2009).

The foregoing results indicate that castor plants have performed well in terms of heavy metal accumulation in their biomass. A substantial amount of metals was extracted from the soil and was accumulated in plant parts (roots, leaves, stem). This has proved castor plants to be good phytoremediators of heavy metals from contaminated soils. The use of castor plants for 
phytoremediation of contaminated soils has another advantage: these plants can be widely used only for this purpose because they are not an edible crop. Because of its wide leaves and greater amount of biomass, the castor beans can perform better as compared to other plants. After metal uptake by plants was compared, non-significant differences were found between both the cultivars.

\section{ACKNOWLEDGEMENTS}

The study was carried out with the support of Pakistan Science Foundation (PSF), Islamabad, Pakistan.

\section{REFERENCES}

Abreu CA, Coscione AR, Pires AM, Paz-Ferreiro J. Phytoremediation of a soil contaminated by heavy metals and boron using castor oil plants and organic matter amendments. J Geochem Explor. 2012;123:3-7.

Allen SE, Grimshaw HM, Rowland AP, Moore PD, Chapman SB. Methods in plant ecology: Chemical analysis. London: Blackwell Scientific Publication; 1986. p.285-344.

Al-Wabel M. The use of natural clay deposits for controlling the hazards of irrigating calcareous soils with zinc and cadmium rich water. J Appl Sci. 2007;7(2):242-7.

Atibu EK, Devarajan N, Thevenon F, Mwanamoki PM, Tshibanda JB, Mpiana PT, Poté J. Concentration of metals in surface water and sediment of Luilu and Musonoie Rivers, Kolwezi-Katanga, Democratic Republic of Congo. Appl Geochem. 2013;39:26-32.

Back P-E and Rosén L. Economic Valuation of contamination risks and its effect on site investigations. In: VALDOR 2006 (Values in Decisions on Risk). Andersson, K (Editor). Congrex: Stockholm; 2006. 68-75p.

Bauddh K, Singh RP. Growth, tolerance efficiency and phytoremediation potential of Ricinus communis (L.) and Brassica juncea (L.) in salinity and drought affected cadmium contaminated soil. Ecotoxicol Environ Safety. 2012;85:13-22.

Berman P, Nizri S, Wiesman Z. Castor oil biodiesel and its blends as alternative fuel. Biomass Bioenergy. 2011;35(7):2861-6.

Chen B-C, Lai H-Y, Juang K-W. Model evaluation of plant metal content and biomass yield for the phytoextraction of heavy metals by switchgrass. Ecotoxicol Environ Saf. 2012;80:393-400.

Cundy A, Bardos R, Church A, Puschenreiter M, Friesl-Hanl W, Müller I, et al. Developing principles of sustainability and stakeholder engagement for "gentle" remediation approaches: The European context. J Environ Manage. 2013;129:283-91.

Gregory JT, Crowder AA. Uptake and accumulation of heavy metals by Typhalatifolia in wetlands of the Sudbury, Ontario region. Can J Bot. 1983;61(1):63-73.

Homer FA, Reeves RD, Brooks RR, Baker AJ. Characterization of the nickel-rich extract from the nickel hyperaccumulator Dichapetalum gelonioides. Phytochemistry. 1991;30(7):2141-5.

Khan K, Lu Y, Khan H, Ishtiaq M, Khan S, Waqas M, et al. Heavy metals in agricultural soils and crops and their health risks in Swat District, northern Pakistan. Food Chem Toxicol. 2013;58:449-58.

Knezevic M, Stankovic D, Krstic B, Nikolic MS, Vilotic D. Concentrations of heavy metals in soil and leaves of plant species Paulownia elongata SY Hu and Paulownia fortunei Hemsl. Afr J Biotechnol. 2009;8(20):5422-9.

Kozanecka T, Chojnicki J, Kwasowski W. Content of heavy metals in plant from pollution-free regions. Polish J Environ Stud. 2002;11(4):395-400.

Kumar S, Malik R, Dahiya I. Influence of different organic wastes upon water retention, transmission and contact characteristics of a sandy soil. Soil Res. 1985;23(2):131-6.

Lindsay WL, Norvell WA. Development of a DTPA Soil Test for Zinc, Iron, Manganese, and Copper. Soil Sci Soc Am J. 1978;42(3):421-8. 
Mahmood A, Malik RN. Human health risk assessment of heavy metals via consumption of contaminated vegetables collected from different irrigation sources in Lahore, Pakistan. Arabian J Chem. 2014;7(1):91-9.

Niu Z-X, Sun LN, Sun T-H, Li Y-S, Hong W. Evaluation of phytoextracting cadmium and lead by sunflower, ricinus, alfalfa and mustard in hydroponic culture. J Environ Sci. 2007;19(8):961-7.

Olivares AR, Carrillo-González R, González-Chávez MCA, Hernández RMS. Potential of castor bean (Ricinus communis L.) for phytoremediation of mine tailings and oil production. J Environ Manage. 2013;114:316-23.

Peng K, Luo C, Lou L, Li X, Shen Z. Bioaccumulation of heavy metals by the aquatic plants Potamogeton pectinatus L. and Potamogeton malaianus Miq. and their potential use for contamination indicators and in wastewater treatment. Sci Total Environ. 2008;392(1):22-9.

Perveen S, Shah Z, Nazif W, Shah S, Ihsanullah I, Shah H. Study on accumulation of heavy metals in vegetables receiving sewage water. J Chem Soc Pak. 2011;33(2):220-7.

Puschenreiter M, Wieczorek S, Horak O, Wenzel WW. Chemical changes in the rhizosphere of metal hyperaccumulator and excluder Thlaspi species. J Plant Nutr Soil Sci. 2003;166(5):579-84.

Schat H, Llugany M, Bernhard R, Metal-specific pattern of tolerance, uptake, and transport of heavy metals in hyperaccumulating and non-hyperaccumulating metallophytes. Terry N, Bañuelos G. editors. Phytoremediation of contaminated soils and water. Lewis Publishers: 2000. p.178-95.

Steel RGD, Torrie JH. Principles and procedures of statistics. 2nd. ed. New York: McGraw Hill Book; 1984. 754p.

Tangahu BV, Sheikh Abdullah SR, Basri H, Idris M, Anuar N, Mukhlisin M. A Review on heavy metals (As, Pb, and Hg) uptake by plants through phytoremediation. Int J Chem Eng 2011. 939161. Available from, DOI: 10.1155/2011/939161

Uena D, Zhao F-J, Shen R, Ma JF. Cadmium and zinc accumulation by the hyperaccumulator Thlaspi caerulescens from soils enriched with insoluble metal compounds. Soil Sci Plant Nutr. 2004;50(4):511-5.

Wiszniewska A, Hanus-Fajerska E, Muszyñska E, Ciarkowska K. Natural organic amendments for improved phytoremediation of polluted soils: a review of recent progress. Pedosphere. 2016;26(1):1-12.

Yi Y, Yang Z, Zhang S. Ecological risk assessment of heavy metals in sediment and human health risk assessment of heavy metals in fishes in the middle and lower reaches of the Yangtze River basin. Environ Poll. 2011;159(10):2575-85.

Zacchini M, Pietrini F, Mugnozza GS, Iori V, Pietrosanti L, Massacci A. Metal tolerance, accumulation and translocation in poplar and willow clones treated with cadmium in hydroponics. Water Air Soil Poll. 2009;197(1-4):23-34.

Zeittouni CF, Berton RS, Abreu CA. Phytoextraction of cadmium and zinc from an oxisol contaminated with heavy metals. Bragantia. 2007;66(4):649-57.

Zhi-Xin N, Li-Na S, Tie-Heng S, Yu-Shuang L, Hing W. Evaluation of phytoextracting cadmium and lead by sunflower, ricinus, alfalfa and mustard in hydroponic culture. J Environ Sci. 2007;19:961-7. 